Biografistyka Pedagogiczna

Rok 4 (2019) $\mathrm{nr} 1$

ISSN 2543-6112; e-ISSN 2543-7399

DOI: $10.36578 /$ BP.2019.04.18

Ryszard Skrzyniarz

\title{
Rodzina Marii Kunowskiej-Porębnej jako środowisko wychowawcze
}

\section{The Family as an Educational Environment in the Memories of Maria Kunowska-Porębna}

\begin{abstract}
A family is the foundation of an entire society and an important element of everyone's life. It determines the future of man and is a fundamental group accompanying man at all stages of their development. It is the most durable and universal institution. A family environment is extremely important in the process of shaping the personality of an individual. A child learns the first patterns of behaviour, norms and values from their parents and relatives. The process of shaping a child's personality through identification with parents depends on a specific style of upbringing in a family, which aims to regulate the mutual relations between its members. The purpose of the article is to show the educational environment in the family of Stefan and Helena Kunowscy based on the memories of Maria Kunowska-Porębna, a daughter of Professor Stefan Kunowski, a teacher at the Catholic University of Lublin. Maria's accounts about the educational role of her parents and the family environment occupy a special place in them.
\end{abstract}

Keywords: family, educational environment, Stefan Kunowski, memories.

* Ryszard Skrzyniarz (ORCID 0ooo-0oo2-1732-8155) - doktor habilitowany, profesor Katolickiego Uniwersytetu Lubelskiego Jana Pawła II, kierownik Katedry Biografistyki Pedagogicznej w Instytucie Pedagogiki kUL, kontakt: skrzyniarz@kul.pl. 


\section{Rodzinne środowisko wychowawcze}

Najstarszą grupą społeczną, jaka ukształtowała się w historii rozwoju cywilizacji i kultury ludzkiej, jest rodzina. Stanowi ona fundament, na którym opiera się całe społeczeństwo, jest istotnym elementem życia każdego człowieka. W rodzinie człowiek funkcjonuje od urodzenia do śmierci. Rodzina decyduje o przyszłości człowieka i stanowi zasadniczą grupę znajdującą się we wszystkich historycznych etapach rozwoju ludzkości. Jest instytucją najbardziej trwałą i uniwersalną, a jej członkowie mają niezwykle zażyłe stosunki interpersonalne oraz wyjątkowy rodzaj współdziałania ${ }^{1}$. Współcześnie pod wpływem głłębokich przemian społecznych, kulturowych i cywilizacyjnych rodzina jako wspólnota i środowisko wychowawcze staje przed poważnym zagrożeniem ze strony różnych ideologii, które usiłują wyjaśnić według własnych koncepcji fenomen życia i wychowania tak często różny z tym, czego oczekuje rodzina. Rodzina jest pierwszym środowiskiem wychowawczym. Stanowi ona początek samodzielnej drogi we wspólnocie ${ }^{2}$.

Danuta Opozda podkreśla, że człowiek w rodzinie „biologicznie przychodzi na świat, wzrasta i dojrzewa fizycznie, w niej kształtują się podstawy jego osobowości i życia psychicznego, a także zainicjowany jest i wyznaczony kierunek jego drogi życiowej i określana wartość własnej egzystencji, w niej nabiera kształtu jego człowieczeństwo i wzrost duchowy"3. Natomiast Barbara Kiereś używa niezwykle trafnego (zarówno w odniesieniu do małżonków, jak i całej wspólnoty rodzinnej) określenia „komunia”4. Stwierdziła ona, że rodzina jest przestrzenią, w której członkowie „wzajemnie obdarowują się człowieczeństwem”.

1 W. Korzeniowska, U. Szuścik, Rodzina. Historia i współczesność, Kraków 2005, s. 140-141.

2 J.Wilk, Pedagogika rodziny, Lublin 2016, s. 35 i nn.; M. Filipowicz, Rodzina jako pierwsze środowisko wychowawcze. Zadania i ideały wychowawcze - z perspektywy nauczania Kościoła, „Łódzkie Studia Teologiczne”, 26 (2017) nr 1, s. 127-144; także: J. Izdebska, Dziecko - dzieciństwo - rodzina - wychowanie rodzinne. Kategorie pedagogiki rodziny w perspektywie pedagogiki personalistycznej, Białystok 2015.

3 D. Opozda, Pedagogiczna wielowymiarowość rozwoju osób w rodzinie, w: Rodzina przestrzenia rozwoju osoby. Perspektywa pedagogiczna, red. M. Jeziorański, D. Opozda, A. Rynio, Lublin 2012, s. 18.

4 B. Kiereś, Tylko rodzina!, Lublin 2006, s. 46-47.

5 Tamże, s. 47. 
Rodzina jest niezmiernie ważna w procesie kształtowania osobowości jednostki - jest bowiem grupą odniesienia, z którą się ona identyfikuje i utożsamia. Od rodziców dziecko uczy się pierwszych wzorów postępowania, norm i wartości, które później zazwyczaj powiela w życiu. Proces kształtowania się osobowości dziecka przez identyfikację z rodzicami uzależniony jest od istnienia w rodzinie określonego stylu wychowania, który ma na celu regulację wzajemnych stosunków między jej członkami. W literaturze pedagogicznej znajdujemy następujące kryteria podziału stylów rodzicielskiego wychowania: demokratyczny, liberalny, niekonsekwentny i autokratyczny ${ }^{6}$, najkorzystniejszy jest styl demokratyczny.

Rodzice jako pierwsi wychowawcy dziecka poprzez swoje postawy i zaangażowanie pomagają mu odkrywać wartości międzyludzkie, rozumieć i przyjmować stawiane wymagania oraz prowadzić dialog wychowawczy, co pozwala wychowywać je ku wartościom. Można więc mówić, że „wychowanie jest osobowym spotkaniem i dialogiem wychowawcy-mistrza i ucznia, który wspomaga wychowanka we wprowadzaniu w świat wartości, prowadząc go tym samym do pełni rozwoju osobowego, do głębi człowieczeństwa"7.

Celem artykułu będzie ukazanie rodziny Kunowskich jako środowiska wychowawczego w oparciu o wspomnienia Marii Kunowskiej-Porębnej, córki profesora Stefana Kunowskiego. Szczególne miejsce zajmą w nich relacje Marii o roli wychowawczej rodziców i środowiska rodzinnego. Aby opisać, jak wyglądało środowisko wychowawcze w rodzinie, w której wzrastała, należy najpierw przyjrzeć się jej krótkiej biografii, a dopiero później wskazać na środowisko rodzinne, które wywarło wpływ na jej wychowanie.

\section{Biografia Marii Kunowskiej-Porębnej}

Bohaterką moich rozważań jest Maria Kunowska-Porębna, jedyna córka profesora Stefana Kunowskiego (1909-1977) i Heleny z domu Szulakiewicz. Była to rodzina mieszczańska o tradycjach robotniczo-inteligenckich. Maria Klara

6 A. Łuczyński, Dzieci w rodzinach zastępczych i dysfunkcyjnych, Lublin 2008, s. 37-38; E. Sozańska, Rodzina jako środowisko wychowania w wartościach, „Łódzkie Studia Teologiczne", 23 (2014) nr 3, s. 39-51.

7 K. Chałas, Wychowanie ku wartościom. Elementy teorii i praktyki, t. 1, Lublin-Kielce 2003, s. 65 . 
urodziła się 4 sierpnia 1937 r. w Lublinie. W latach 1944-1951 uczęszczała do Szkoły Podstawowej Sióstr Urszulanek w Lublinie. W 1951 r. przeszła do VIII Liceum Ogólnokształcącego Sióstr Urszulanek, które ukończyła maturą 2 czerwca 1955 r. W latach 1955-1960 studiowała filologię polską na Wydziale Nauk Humanistycznych Katolickiego Uniwersytetu Lubelskiego, tam uzyskała tytuł magistra filologii polskiej. W latach 1960-2002 pracowała na KUL, zajmując się badaniami nad literaturą. Jest autorką ok. 100 publikacji, w tym haseł w Encyklopedii katolickiej i Polskim słowniku biograficznym oraz innych słownikach, artykułów w czasopismach i pracach zbiorowych, czasopismach naukowych i popularnonaukowych, a także współautorką i redaktorką. Bardzo aktywnie działała w NSzZ „Solidarność" na KUL. W latach 1982-1989 była łącznikiem w Biurze Informacji Regionu Środkowo-Wschodniego. Jest matką dwóch córek ${ }^{8}$.

\section{Wychowanie i edukacja w rodzinie Kunowskich}

Na wychowanie i edukację Marii miało wpływ kilka pokoleń rodzinnych. Zaczynając od dziadków, przez rodziców, stryjka Antolka po ciocie: Niutę - Janinę Szulakiewicz i Marię Kunowską oraz „przyszywaną” ciocię Cianię - Janinę Nartowską. Bohaterka tego artykułu, mając dwie córki, wychowywała je w kręgu rodzinnym, powielając wzór wyniesiony z własnej familii. Postaram się przedstawić wychowanie i edukację Marii w ujęciu chronologiczno-problemowym.

\section{Dziadkowie}

Niewątpliwie znaczącą rolę w wychowaniu dzieci odgrywali dziadkowie, którzy nie byli już tak rygorystyczni wobec wnucząt, jak byli wobec swoich dzieci. Maria opowiada o dziadku Józefie Poppe, który był muzykiem i sam edukował muzycznie swoje dzieci, które w przyszłości próbowały uczyć następne pokolenia: dzieci swoje oraz znajomych i przyjaciół.

8 Biografię opracowałem na podstawie: AU KUL, Akta osobowe studentów, Kunowska Maria, sygn. H 15145; Akta pracownicze, Kunowska-Porębna Maria, sygn. A-981; J. Gawrysiakowa, M. Józwik, NSzZ „Solidarność” w Katolickim Uniwersytecie Lubelskim 1980-2010, Lublin 2015, s. 77, 89; Wspomnienia Marii Kunowskiej-Porębnej, wydał, opracował, wstępem i przypisami opatrzył R. Skrzyniarz, Lublin 2018, s 11-13. 
Artystyczna dusza cioci chciała się realizować w dziedzinie muzyki. Nawiasem mówiąc, rodzina była tradycyjnie muzyczna - głowa rodziny Józef Poppe grywał na fortepianie [...]. Kładł nacisk na muzyczną edukację dzieci. Pilnował, żeby ćwiczyły, gdy spał po obiedzie. W momencie, gdy delikwent przerywał przekonany, że ojciec śpi, ten budził się automatycznie. Z generacji jego wnuczek grały: ciocia Stasia, ciocia Niuta i ciocia Cesia. Niuta w pewnym momencie, już jako osoba pracująca, brała lekcje u najbardziej renomowanej nauczycielki Lublina, nota bene bardzo drogiej. Jednak nie dane jej było rozwijać talentu. W rezultacie skończyła jako nauczycielka muzyki. Za mojej pamięci edukowała - poza wojenną Blanką - Lalę i córkę swojej koleżanki - Krysię. Te lekcje odbywały się u nas. Próbowała edukować i mnie, ale byłam wyjątkowo oporna?.

Jak wynika z powyższego cytatu pradziadek Poppe osobiście nie edukował Marii, ale talenty zaszczepione dzieciom owocowały w edukacji młodych pokoleń. Maria była uczona przez ciocię Niutę. Z ciotką wojowała jednak i buntowała się przeciw grze na fortepianie ${ }^{10}$.

Na wychowanie i edukację Marii duży wpływ miała jej babcia Celina Szulakiewicz z domu Poppe, która była osobą bardzo wierzącą i utrzymywała rozległe kontakty z duchowieństwem nie tylko Lublina. Prenumerowała katolickie pisma, które były dla wnuczki lekturą dzieciństwa, wspomina ona, jak oglądała publikowane w nich obrazki, a później czytała nie tylko w czasie choroby:

Kiedy chorując, bardzo naprzykrzałam się otoczeniu, w nagrodę za grzeczne sprawowanie otwierano mi tapczan. Był to dla mnie istny sezam, w skrzyni bowiem leżały roczniki przedwojennych czasopism - mnie interesowały wyłącznie ilustrowane. Należał do nich babciny „Głos Karmelu”. Babcia Celina obracała się w kręgu duchowości karmelitańskiej - należała do Trzeciego Zakonu Karmelitańskiego, utrzymywała bliski kontakt z ojcami lubelskiego konwentu, szczególnie z o. Janem Sową. W ramach tych kontaktów brała udział w corocznym strojeniu Grobu Bożego u karmelitów. Prenumerowała "Głos Karmelu” - na jednej z laurek wnuk upamiętnił babcię trzymającą to pismo. W „Głosie Karmelu” nie miałam wiele „strawy dla oczu”. Podobała mi się charakterystyczna figurka Dzieciątka w żłóbku i wizerunki Matki Boskiej Szkaplerznej. Natomiast plastyczne

9 Wspomnienia Marii Kunowskiej-Porębnej, s. 82.

10 Tamże, s. 85. 
ujęcia przeżyć mistycznych gorliwie omijałam, gdyż nie przemawiała do mnie estetyka tych wizji ${ }^{11}$.

Szczególnie w okresie okupacji niemieckiej, gdy dostęp do polskich książek i czasopism był utrudniony, zdeponowane w tapczanie pisma służyły do czytania oraz oglądania obrazków. Dla Marii były one źródłem nauki, rozwijania dziecięcej wyobraźni, zabawy i poznawania świata, co prawda bardzo okrojonego i jednostronnego, a czasem nawet nierealnego, ale tego, który ją zachwycał lub czasami odstręczał przez ponure rysunki czy opowiastki znajdowane na kartach niektórych czasopism lub książek ${ }^{12}$.

\section{Rodzice}

Najważniejszą rolę w wychowaniu i edukacji młodej Marii odegrali rodzice. Stefan Kunowski pełnił rolę głowy rodziny, ojca i nauczyciela, wszak był zawodowym pedagogiem ${ }^{13}$. Można by rzec, że to on powinien wiedzieć, jak wychowywać i edukować, jednak tak nie było. W dzieciństwie relacje ojca z córką były bardzo dobre, choć nie był zbyt czułostkowy, okazywał córce troskę i wiele uwagi: dbał o stosowność zabaw. Gdy była mała, uczestniczył w jej zabawach, rysując obrazki i przygotowując ozdoby świąteczne. Troszczył się także o odpowiednie lektury i edukację córki. Choć Maria nie lubiła, gdy chciał z nią odrabiać lekcje. „Pomoc taty w moich lekcjach zawsze kończyła się gwałtownie - ze strony taty było to zniecierpliwienie, z mojej... potoki łez" ${ }^{\prime 14}$. O relacjach z ojcem w tamtym czasie pisze ona:

Nigdy nie były one specjalnie czułostkowe. Jakiegoś przytulania czy głaskania nie pomnę. Nie było też i bicia. Za karę stało się w kącie lub klęczało na kolanach, czasem obrywało „po łapach". Chwalił niezwykle oszczędnie wyrazem największego uznania było stwierdzenie: „Może być”. I to nie tylko w stosunku do mnie.

11 Tamże, s. 120-121.

12 Tamże, s. 118-119.

13 Stefan Kunowski (1909-1977), pedagog, polonista, psycholog, profesor i wykładowca pedagogiki na Katolickim Uniwersytecie Lubelskim, R. Skrzyniarz, Kunowski Stefan, w: Encyklopedia 100-lecia KUL, t. 1, Lublin 2018, s. 601.

14 Wspomnienia Marii, s. 84 . 
Stefan Kunowski należał do osób bardzo spolegliwych i cierpliwych wobec swoich studentów - według powszechnie przyjętej opinii ${ }^{15}$ - tym bardziej więc dziwi jego zachowanie wobec córki. Być może włączał się tu tryb rodzicielskiego nadzoru i wyśrubowanych ambicji wobec jedynaczki. Można rzec, że władza rodzicielska i wynikające z niej obowiązki były przedkładane przez ojca ponad miłość ojcowską, która schodziła na dalszy plan. Dlatego w początkowych klasach Maria lekcje odrabiała z mamą. Ojciec natomiast wspierał córkę w działalności plastycznej, niekiedy jednak wykazywał w niej zbyt wiele fantazji:

Mama zawsze twierdziła, że nie umie rysować, więc gdy w trzeciej klasie trzeba było w zeszycie do przyrody przekalkować kaczkę, wezwała na pomoc tatę. Sprawnie rysujący tata poradził sobie z zadaniem bardzo szybko, ale z nadmiaru fantazji dorysował na łebku kaczki czubek, którego nie było na obrazku. Z powodu tego czubka „popadłam w rozpacz”, jak ja ten zeszyt pokażę?

Maria wspomina, że w domu i na podwórku obowiązywała pedagogika zakazów - jak ją nazywa. Nie wolno jej było niczego ruszać na biurku ojca ani pożyczać książek ${ }^{17}$. Na podwórku nie mogła się bawić koło śmietnika, choć to lubiła, bo tam było można znaleźć różne „skarby”. Zakaz obejmował również zabawę w bramie i w sieniach. Maria zapisała co prawda, że: „pakiet” zakazów podwórkowych był autorstwa cioci Niuty, która była odpowiedzialna za jej bezpieczeństwo, „robiła więc, co mogła, żeby nie spuszczać mnie z oczu”18.

Gdy Maria zaczęła dorastać, prof. Kunowski, jak często ojcowie, nie potrafił zaakceptować szybkiego dojrzewania córki. Obawiał się, czy w trudnych warunkach Polski „ludowej” nie ulegnie ona pokusie zachłyśnięcia się „nowoczesnością", zafascynowania stylem życia, którego nie akceptował. Ich stosunki uległy więc pogorszeniu, pojawiły się nieporozumienia, niedomówienia, rozdźwięki. Dorastająca dziewczyna oczekiwała od ojca wsparcia, tymczasem dostawała utyskiwania i nakazy. Z perspektywy czasu autorka wspomnień dostrzegła:

15 Tamże, s. 65.

16 Tamże, s. 83.

17 Tamże, s. 93.

18 Tamże, s. 83. 
Tacie zaczęłam się stawiać przed maturą. Dotarło do mnie wtedy, że mam bardzo ubogą garderobę, a tata przecież tyle wydaje choćby na pisma. Ale to było preludium mojego „wybijania się na niepodległość”. Prawdziwe utarczki przyszły w okresie studiów ${ }^{19}$.

Sytuacja uległa pogorszeniu, gdy Maria rozpoczęła studia:

W tym czasie stosunki z tatą stały się napięte. Kiedy przyjrzałam się krytycznie moim studenckim „wyczynom”, stwierdziłam, że urszulińskie „pisklę" bardzo szybko rozwinęło skrzydła. Tata, przyzwyczaiwszy się do względnie spokojnego rytmu, nie był nastawiony na tak szybkie zmiany. Bał się, że wpadnę w złe towarzystwo. Ostrzegał przed kawiarniami. Kiedyś powiedział, że z kawiarni nie wychodzą święci. A ja w ciągu całych studiów w kawiarni byłam cztery razy, z tego trzy „na wyjeździe” i raz byłam na dancingu, też poza Lublinem. Po prostu nie miałam czasu.

Z tatą nie umieliśmy znaleźć wspólnego języka. Był podejrzliwy. Być może była to cecha rodzinna, bo ciocia Marysia stale podejrzewała mnie o najgorsze. [...] A my (tata i ja) co rusz skakaliśmy sobie do oczu, mając w tym samym miejscu wady i cnoty ${ }^{20}$.

We wspomnieniach pisze, że w domu nie mówiło się o seksie. Jednak szybko dodaje, że to była taka epoka. Problematyka wychowania seksualnego nie była poruszana tylko w jej rodzinie, ale i w domach jej koleżanek:

Pamiętam, że w książce od biologii koleżanki odpowiednie strony były zagięte i jej mama zakazała jej tam zaglądać. Broszury na ten temat otrzymały koleżanki dopiero po maturze i to tylko te, które mieszkały w internacie ${ }^{21}$.

Już w okresie studiów Maria miała narzeczonego, co niekoniecznie było akceptowane przez rodziców, a szczególnie przez ojca, który zapewne chciał wydać swoją córkę za mąż za najlepszą partię z możliwych. Niewykluczone, że dlatego iskrzyło na linii ojciec Marii - narzeczony Jerzy. Często pośrednikiem i mediatorem w stosunkach ojca z córką była matka:

19 Tamże, s. 86.

20 Tamże, s. 92.

21 Tamże, s. 92-93. 
Jako z temperamentu choleryk [ojciec - R. S.] był wybuchowy. Stąd większość różnych pozwoleń dla mnie załatwiała mama. Kiedyś zaistniała taka sytuacja, że zgoda dla taty była z jakichś powodów wyjątkowo trudna. $\mathrm{Na}$ to przyzwolenie czekaliśmy z narzeczonym w dużym pokoju, a mama „urabiała” tatę w pomieszczeniu obok. Zdenerwowany tata podnosił głos, a mama uciszała go. W końcu tata krzyknął: „Co cicho, co cicho, niech słyszy" (chodziło o narzeczonego).

W innym przypadku zaś: „gdy grał z moim mężem w szachy, po kilkakrotnej przegranej szurnął gwałtownie figury z szachownicy. Figury rozleciały się po podłodze, a tata wstawszy zza stołu, poszedł do swojego pokoju"22.

Ojciec zajmował się także wychowaniem kuzynów:

Odkąd zamieszkiwał u nas Waldek, codziennym gościem był jego przyjaciel Fredek. Ponieważ Fredek był półsierotą, tata jakoś automatycznie mu „ojcował". Sprawdzał obu chłopakom lekcje, a za złe stopnie brali równo sobotnią „wypłatę" po siedzeniu. Tata „trzepał im portki” ręką, więc gdy Waldek wpadł na pomysł włożenia do tylnej kieszeni malutkiej stolnicy dla lalek, sprawa wydała się natychmiast i delikwent poniósł podwójną karę. Gdy chłopcy zaczęli interesować się dziewczętami, mogli całymi godzinami wysiadywać na niskim płotku pod oknem Reni i Halinki. Na tę okoliczność tata ułożył wierszyk, z którego pozostało mi w pamięci tylko zakończenie: „Podpisano i przybito Ferdynand Kopyto”23.

Należy zaznaczyć, że w omawianym okresie - po drugiej wojnie świtowej - używanie silnej ręki czy, jak to napisała Maria, „trzepanie portek” nie było niczym nadzwyczajnym i wchodziło do kanonu zachowań akceptowanych podczas wychowywania dzieci i młodych osób, co dzisiaj nieco może dziwić.

Zdecydowanie inną rolę w wychowaniu Marii pełniła matka. We wspomnieniach Maria poświęciła jej zdecydowanie mniej miejsca niż ojcu. Być może wynikało to z tego, że była ona osobą nierzucającą się w oczy, spokojną i stonowaną. Te cechy umożliwiały jej zażegnywania konfliktów w rodzinie i wśród najbliższego otoczenia, pomagały także w utrzymywaniu dobrych relacji w mieszkaniu, w którym państwo Kunowscy przez 17 lat musieli współistnieć

22 Tamże, s. 96.

23 Tamże, s. 49. 
z drugą rodziną: „[...] mama łagodziła wszelkie spięcia, a zauważyć trzeba, że sąsiadka była osobą wybuchową" ${ }^{24}$. Matka dbała, aby ojciec mógł pracować naukowo w dość trudnych warunkach, np. dostosowała rodzinne spotkania do zadań i obowiązków ojca. Maria wspomina, że matka pochodziła z wielodzietnej rodziny (miała dziesięcioro rodzeństwa), średnio zamożnej. Jednak po śmierci ojca, czyli dziadka Marii, popadła w tarapaty finansowe, dlatego matka dość szybko się usamodzielniła, podejmując pracę, a następnie wychodząc za mąż za Stefana Kunowskiego ${ }^{25}$.

Matka była równocześnie osobą niezwykle energiczną, przedsiębiorczą i dzielną. Nie poddawała się w trudnych sytuacjach życiowych, ale optymistycznie podchodziła do wszelkich niełatwych spraw. Była optymistką i często musiała „studzić” pesymizm i katastrofizm ojca, jego czarnowidztwo potrafiła „spacyfikować" opowiastką o panu Mydełko. A właściwie hasłem „pan Mydełko” rozbrajała go, czasami niestety na bardzo krótko ${ }^{26}$.

Wiara dawała jej wiele sił duchowych do dźwigania trosk i trudów codziennego życia i obowiązków rodzinnych. „Mama siłę do dźwigania życiowych problemów czerpała z wiary"27 - pisze Maria. Od 1927 r. należała do Trzeciego Zakonu Karmelitańskiego. Utrzymywała liczne kontakty z duchownymi diecezji lubelskiej oraz z werbistami, którzy pracowali na misjach na Dalekim Wschodzie. W latach 1973-1981 zaangażowała się w wysyłanie paczek dla werbistów na misje, szczególnie w Indonezji. W jej domu często gościly Siostry Służebniczki Dębickie ${ }^{28}$.

Oboje rodzice byli religijni. Jak to napisała Maria Kunowska: „Religijność rodziców nie była udziwniona"29. Będąc osobami religijnymi, w wychowaniu córki, a później wnuczek, kierowali się zasadami wiary katolickiej, choć nigdy ich nie narzucali, a jedynie informowali. Maria, gdy wychodziła za mąż, zastrze-

24 Tamże, s. 98.

25 Tamże, s. 97-98.

26 Opowiastkę tę przytoczyła we Wspomnieniach: „Pan Mydełko, urzędnik magistracki, wracał po pracy do domu. Na balkonie trzeciego piętra służąca trzepała jego futro. W pewnej chwili futro spadło, a pan Mydełko bardzo się zmartwil: Co by było, gdybym ja był w tym futrze?" (s. 94-95).

27 Wspomnienia Marii, s. 99.

28 Tamże, s. 99-101.

29 Tamże, s. 101. 
gła sobie, że rodzice nie mogą jej kupić żadnego „świętego obrazu”, gdyż chciała zdecydować sama, jaki obraz lub figurkę umieści w swoim mieszkaniu i tak też uczyniła. Rodzice uszanowali jej decyzję ${ }^{30}$.

Po ślubie, gdy Maria usamodzielniła się, rodzice sporadycznie odwiedzali młodą rodzinę. Ponieważ jednak dzieci stołowały się u nich, utrzymywali częste kontakty. Niestety nawet sporadyczne wizyty kończyły się uwagami, szczególnie ojca:

Na nowe mieszkanie częściej przychodziła mama, tata zjawiał się rzadko. Jedna z jego wizyt przypadła w marcu, a ja nie rozebrałam naszej choinki, bo mi było szkoda. Oberwałam wtedy nieźle. Wizyty rodziców na ogół nie były częste, choćby z tej przyczyny, że stołowaliśmy się stale u rodziców, był więc codzienny kontakt ${ }^{31}$.

Rodzice troszczyli się o swoją córkę. Troska ta objawiała się w kontrolowaniu jej szczególnie przez ojca. Z matką lepiej się dogadywała i znajdowała wspólny język. Charakterologicznie była podobna do ojca, ale to matka była jej powierniczką i pośredniczką w relacjach z ojcem.

Rodzice Marii - Helena i Stefan Kunowscy, jako dziadkowie zajmowali się wnuczkami, czynnie uczestnicząc w ich wychowaniu oraz edukacji.

Opuszczenie mieszkania przez sąsiadów pozwoliło mi się na nowo wprowadzić do domu, tym razem wspólnie z mężem. Wkrótce na świat przyszła nasza pierwsza córka, Monika Agnieszka. Mama pomagała w pielęgnacji i wychowaniu dziecka. Gdy trochę „dojrzało”, tata rozwinął nad nim wychowawcze skrzydła. Na hasło wnuczki „usiasia”, tata odkładał wszelką robotę, nawet najpilniejszą, brał ja na kolana, huśtał w rytm piosenki „jedzie, jedzie pan..., kuj, kuj kowalu...., śpiewał także: „A idziesz ten kusy Janek, co chodził z toporkiem..." W nieskończoność rysował wiejska zagrodę z bocianem na dachu, potem na płocie i kogutem na podwórku, i psem w budzie. Lubił czytać, szczególnie wiersze Janiny Porazińskiej: $Z$ popielnika na Wojtusia iskiereczka mruga, o pająku, który bez ustanku wchodził na poduszki, o nieudanych próbach kota polującego na wróbla siedzącego na dachu. Młodsza nasza córka, Barbara Helena nie miała

30 Tamże, s. 103.

31 Tamże, s. 104. 
takiego szczęścia, bo dziadek chorował i nie mógł zajmować się wnuczką. Zmarł, gdy Basia miała trzy lata ${ }^{32}$.

Nawet czas wypoczynku, który spędzali w Krężnicy, poświęcali na pomoc w wychowaniu wnuczek: Starsza córka „wylądowała” w Krężnicy, mając 6 tygodni. Dziadek woził ją wtedy do „dzięciołka koło kościołka” ${ }^{\text {33. }}$

\section{Ciocie i stryjek}

We wspomnieniach Marii Kunowskiej-Porębnej pojawia się stryjek Antoni zwany przez nią wujkiem Antolkiem. Był młodzieńcem i to on podsunął Marii jako dziecku do czytania kilka numerów „Płomyczka” oraz oprawiony rocznik „Płomyka" ${ }^{4}$.

W sukurs przyszedł najmłodszy brat ojca - Antolek, który oddał do mojej dyspozycji trochę pojedynczych numerów „Płomyczka” i „Płomyka”. [...] Prawdziwym skarbem okazał się oprawiony tom „Płomyka” (1937) od bohatera wiersza Anny Świrszczyńskiej zwany przeze mnie Patałaszkiem ${ }^{35}$.

Znacząca rolę w wychowaniu i edukacji Marii odgrywały ciotki, a szczególnie ciocia Niuta, która mieszkała z rodzicami Marii i kiedy ci szli do pracy, przejmowała opiekę nad Marią:

Wojna zaburzyła ten porządek. Z pozoru zmieniło się niewiele - oboje rodzice pracowali, od końca października 1939 roku opiekę nad domem przejęła ciocia Niuta. Spędziłyśmy razem tak wiele czasu, że ja w swojej naiwności (III czy IV klasa) napisałam w wypracowaniu, że wychowywała mnie... ciocia, co bardzo obruszyło rodziców ${ }^{36}$.

Druga ciotka, Maria Kunowska, mimo że trochę „nieoswojona” przez rodzinę, miała także swój wpływ na wychowanie Marii, swojej bratanicy. Choć była

32 Tamże, s. 99. Monika Agnieszka urodziła się w 1967 r., a Barbara Helena urodziła się w 1974 r. Stefan Kunowski zmarł 15 września 1977 r.

33 Tamże, s. 113.

34 Tamże, s. 30, 119.

35 Tamże, s. 119.

36 Tamże, s. 77-78. 
w ciągłym kontakcie z rodziną, to: „nie akceptowała mamy i mnie. Stale zgłaszała uwagi co do stylu wychowania mojego i moich dzieci" ${ }^{37}$.

Maria urodziła się w katolickiej, wierzącej i praktykującej rodzinie. W jej wychowaniu od samego początku bardzo ważna była modlitwa, o którą troszczyła się cała rodzina.

Jako pierwszy element tatowych wpływów wychowawczych dostrzegam... modlitwę. Otóź popularne wezwanie „Aniele Boże” dotarło do mnie w formie skróconej bez słów „Strzeż duszy, ciała mego i zaprowadź mnie do żywota wiecznego"38.

Wychowanie katolickie emanuje w całych wspomnieniach Marii Kunowskiej-Porębnej. Swoją opowieść zaczyna od opisu świąt katolickich i ich roli w życiu całej rodziny. Jej rodzina była ściśle związana ze środowiskiem kościelnym, nie tylko gościła w domu księży i siostry zakonne, ale także czynnie uczestniczyła w życiu religijnym parafii pw. Nawrócenia św. Pawła i kościele rektoralnym pw. Wniebowzięcia Najświętszej Maryi Panny Zwycięskiej. Jako matka Maria sama także wychowywała dzieci w wierze katolickiej i przekazywała im wartości religijne i prawdy wiary wyniesione ze środowiska rodzinnego i Kościoła ${ }^{39}$.

\section{Podsumowanie}

Poniższy cytat świetnie oddaje atmosferę i rolę jaką odgrywali rodzice w wychowaniu Marii, mimo, że ta była edukowana także przez ciocie Nitę i Marię, stryja Antolka, kuzynkę Basię oraz tzw. przyszywane ciocie, np. Cianię - Janinę Nartowską. To jednak rola rodziców była decydująca. „Rygor szkolny i autorytet rodziców to były podstawowe "prowadnice« mego wychowania. Z ciocią natomiast wojowałam - zbuntowałam się przeciw grze na fortepianie, nie zawsze chciałam wykonywać jej polecenie" ${ }^{\prime 40}$.

Mimo trudnych relacji Marii z ojcem, istniała miedzy nimi więź emocjonalna. Zawdzięczała mu dużo, choć w wielu kwestiach się z nim nie zgadzała,

37 Tamże, s. 74.

38 Tamże, s. 82.

39 Tamże, s. 29-41, 183-201.

40 Tamże, s. 85. 
co prowadziło do konfliktów i sporów. Matka zaś była w stosunkach z ojcem mediatorką. We wspomnieniach nie ma żadnej informacji, że relacje z matką i jej wpływ na wychowanie były powierzchowne lub nieistotne. Można wnosić, że Maria wzór matki i żony czerpała ze swojej matki. Na jej wychowanie największy wpływ wywarli jednak rodzice, a treść jej wspomnień dobitnie świadczy o tym, że jej późniejsze postawy - może czasami mimo buntu - były wzorowane na postaciach rodziców.

Streszczenie: Rodzina jest pierwszym środowiskiem wychowawczym. Rodzice i najbliższa rodzina mają największy wpływ na wychowanie i edukację młodego pokolenia. Jednak wychowanie nie kończy się na wychowaniu rodzinnym, a jest to dopiero początek samodzielnej drogi we wspólnocie. $W$ artykule zostało ukazane rodzinne środowisko wychowawcze w rodzinie Kunowskich. Kanwą tej analizy były wspomnienia Marii Kunowskiej-Porębnej - jedynej córki prof. Stefana Kunowskiego pedagoga Katolickiego Uniwersytetu Lubelskiego. Maria była wychowywana przez rodziców, ale także przez środowisko rodzinne: dziadkowie, stryjek, ciocie, tzw. „przyszywana ciocia”, to jednak największy wpływ w jej wychowaniu odegrali rodzice. Najlepsze relacje miała z matką. Mimo trudnych relacji Marii z ojcem, istniała miedzy nimi więź emocjonalna. Zawdzięczała mu wiele, choć $\mathrm{w}$ wielu kwestiach się z nim nie zgadzała, co prowadziło do nieporozumień.

Słowa klucze: Maria Kunowska-Porębna, Stefan Kunowski, rodzina, wychowanie w rodzinie.

\section{Bibliografia}

\section{Źródła}

Archiwum Uniwersyteckie KUL

Akta osobowe studentów, Kunowska Maria.

Akta pracownicze, Kunowska-Porębna Maria.

Wspomnienia Marii Kunowskiej-Porębnej, wydał, opracował, wstępem i przypisami opatrzył R. Skrzyniarz, Episteme, Lublin 2018.

\section{Opracowania}

Chałas K., Wychowanie ku wartościom. Elementy teorii i praktyki, t. 1, Lublin-Kielce 2003. 
Filipowicz M., Rodzina jako pierwsze środowisko wychowawcze. Zadania i ideały wychowawcze - z perspektywy nauczania Kościoła, „Łódzkie Studia Teologiczne”, 26 (2017) nr 1, s. 127-144.

Gawrysiakowa J., Józwik M., NSzZ „Solidarność” w Katolickim Uniwersytecie Lubelskim 1980-2010, Lublin 2015.

Izdebska J., Dziecko - dzieciństwo - rodzina - wychowanie rodzinne. Kategorie pedagogiki rodziny w perspektywie pedagogiki personalistycznej, Białystok 2015.

Kiereś B., Tylko rodzina!, Lublin 2006.

Korzeniowska W., Szuścik U., Rodzina. Historia i współczesność, Kraków 2005.

Łuczyński A., Dzieci w rodzinach zastępczych i dysfunkcyjnych, Lublin 2008.

Opozda D., Pedagogiczna wielowymiarowość rozwoju osób w rodzinie, w: Rodzina przestrzeniq rozwoju osoby. Perspektywa pedagogiczna, red. M. Jeziorański, D. Opozda, A. Rynio, Lublin 2012.

Sozańska E., Rodzina jako środowisko wychowania w wartościach, „Eódzkie Studia Teologiczne", 23 (2014) nr 3, s. 39-51.

Skrzyniarz R., Kunowski Stefan, w: Encyklopedia 100-lecia KUL, t. 1, Lublin 2018.

Wilk J., Pedagogika rodziny, Lublin 2016. 